\title{
PREFACE TO THE ENGLISH-LANGUAGE EDITION
}

\author{
[ORETTA ZANINI DE VITA]
}

Wheat flour and water. For more than a thousand years, Italian hands have crafted this simple dough into hundreds of different shapes with a creative genius that no other noodle-eating people in the world has rivaled. To me, this heritage is an Italian gift to gastronomic culture on a par with what the Florentine Renaissance gave to art. I am thus proud and delighted that the results of my research are now available to English-language readers.

This book is about the traditional shapes of Italian pasta-the long, the short, the layered, the rolled, the stretched, and the stuffed. A mixture of wheat flour and water recognizable as pasta has existed in many parts of the world since antiquity, but the quantity and the variety of the forms found on the Italian peninsula and islands, served in so many ways, are unique.

My research aimed to sort out and clarify this vast repertoire of shapes and their often ambiguous and confusing names. During a period of about ten years, this work took me throughout Italy to consult documents in public and private archives and in municipal and private libraries and, even more important, to interview hundreds of elderly people whose recollections confirmed what I had read in the written sources.

Because the industrialization of pasta making has, to an extent, altered the traditional nomenclature and shapes, it was essential to consult these oral sources of the old ways. And so I endeavored to record - region by region, valley by valleywhatever remained of this immense and uniquely Italian heritage. The first Italian edition of my results was published in 2004 by the Italian Institute of Rural Sociology. ${ }^{1}$

During the preparation of the English-language edition, non-Italians (as well as more than a few Italians) asked Maureen and me the same two questions over and over. The first, Is it true that Marco Polo introduced noodles into Italy? And the second, Are you going to talk about what sauces go with what shapes? 
The answer to the first question is a resounding no. Dried pasta, the kinds made with durum wheat, is found in Italy from about A.D. 80o. It was, in fact, the Muslim occupiers of Sicily who spread the manufacturing and drying technique. ${ }^{2}$ By the twelfth century, pasta produced in Sicily and Sardinia was being exported to mainland Italian territory and northern Europe, where it was marketed by the powerful maritime republics of Genoa and Pisa. Documents exist to prove this, should there be anyone left-and it appears that there is-who still believes that Marco Polo introduced noodles into Italy in $\mathbf{2} 296$ on his return to Venice from China. In reality, by that time, people throughout Italy had been eating pasta for at least a century. ${ }^{3}$ Marco Polo does relate an encounter with the Chinese noodle and uses the word pasta to describe it, clearly being already familiar with both term and concept. ${ }^{4}$ The notion that spaghetti began in the Far East seems to have originated as recently as 1938 , in Minneapolis, as a marketing gimmick in an article by one L. B. Maxwell in the trade publication Macaroni Journal. ${ }^{5}$

As to the question on sauces, foreigners who are intimidated by the strength and tenacity of Italian food habits, beliefs, and prohibitions will be surprised to learn that the pairing of shapes and sauces is mostly due to tradition. Of course there are a few guidelines-for example, chunky sauces do better on short tubes than on long strings. But by and large, the sauces and condiments are dictated by what people have always done. The shapes in this book are traditional foods, often poor or, if enriched with such expensive ingredients as fish or meat, reserved for rare and important occasions. Sauces were invented from what was on hand. Pairings became first traditional, then canonical, so that today the matching of, say, clam sauce with rigatoni instead of spaghetti-a combination with which there is nothing inherently wrong-still has the power to shock. But this book is not about modern usages, whether codification of the traditional ways or the experiments of creative chefs. Nor does it give recipes or advice to modern cooks. It is a record of what ordinary people did and do and have always done with the available resources. Necessity became tradition, and tradition would appear to have entered the national DNA to the point that Italians instinctively match shape and sauce and get it right.

Tradition, of course, has always been guided by three factors: local products, their seasons, and, most of all, the liturgical calendar. In areas where vegetables were plentiful, the different pasta shapes, everywhere served mostly in soups, came to be paired with various kinds of vegetables. Legumes, on the other hand, are grown everywhere, and are paired with pasta everywhere as well.

The widespread use of the tomato in home kitchens, which began in the early nineteenth century, has brought about a certain uniformity, and since its arrival, tomato sauce has been the most emblematic condiment for pastasciutta, although seasonal vegetables and local cheeses are still used in many parts of the country. In 
Puglia, for example, orecchiette are sometimes dressed with tomato sauce, yes, but when the splendid local turnip greens (cime di rapa) are in season, no one would use anything else. Religious traditions too have influenced how pasta is served, and are treated at length in the individual entries (see, for example, tagliolini for the rituals of Ascension Day in the Vulture area). Meat in sauces was reserved almost exclusively for feast days, and usually involved cuts that were difficult to cook any other way, especially giblets and offal in general. When tradition called for an important cut of meat (always, and still, cooked very slowly over a practically invisible flame), the meat was (and is) served separately as a main course. And the same goes for sauces made with fowl, such as duck or goose.

I will take this opportunity to thank some of the people who have helped me in my work, and first among them are the numerous older people, especially women, some of whom are no longer living, who shared their memories. Next, I owe a grateful mention to my late husband, Carlo De Vita, to whom this book is dedicated. Among so much else, including his moral support during the years of research, he provided material help in reading antique documents and explored the patents section of the Archivio Centrale dello Stato (the Italian national archive) with me. The incomparable Tommaso Lucchetti consulted documents in Umbria and the Marche on my behalf, and Laura Celentano accompanied me on research trips to Basilicata. Last but not least, the pasta makers, notably Benedetto Cavalieri and the entire Martelli family, provided precious information and insights that helped me to put into focus the links between the ancient art of home pasta making and the modern pasta industry.

For the English edition, I thank first of all Maureen B. Fant, who has translated my work with intelligence and rare skill, making even its most abstruse parts comprehensible to non-Italian readers. This is my first publication in the United States, and it has been a privilege and pleasure to work with Darra Goldstein, Sheila Levine, and Dore Brown, of the University of California Press. Our diligent, and diplomatic, copyeditor, Sharon Silva, has been inspiring. Luciana Marini, artist, and Stefano Filippi, photographer, worked closely with me to provide just the right images, and they too have my thanks.

To all, grazie infinite.

\section{Notes}

I. I am grateful to the institute, and to its president, Corrado Barberis, for graciously authorizing this English edition.

2. See spaghetti entry, page 257 . 
3. G. Prezzolini, Maccheroni \& C. (Milano: Rusconi, I998), $67 \mathrm{ff}$.

4. Paolo Rivalta, ed., Il libro di Marco Polo detto il Milione (Torino: Einaudi, 1960), I79. In a subsequent chapter, Marco recounts that the Tartars in their peregrinations had to "dry" their milk like pasta! That certainly implies that the traveler was also familiar with dried pasta, which indeed Venetians had been eating for quite some time.

5. S. Serventi and F. Sabban, La pasta. Storia e cultura di un cibo universale (Roma-Bari: Laterza, 2000), I4. 